\title{
Constellation of Methicillin-Resistant Genomic Islands (SCCmec) among Nasal Meticillin-Resistant Staphylococcus aureus Isolates
}

\author{
Shuaibu Suleiman Adeiza, Josiah Ademola Onaolapo, Busayo Olalekan Olayinka \\ Department of Pharmaceutical Microbiology, Faculty of Pharmaceutical Sciences, \\ Ahmadu Bello University, Zaria, Kaduna, Nigeria
}

SUMMARY

The apprehensiveness for the knowledge vacuum on existential threat of nasal carriage of $p v l+$ healthcare-acquired meticillin-resistant Staphylococcus aureus (HA-MRSA) strains amongst subjects in hospitals have led us to pursue a grasp on the constellation of staphylococcal cassette chromosome mec (SCCmec) types and pol gene among mecA positive MRSA nasal strains. This was accomplished by phenotypic (catalase, coagulase, Microgen staph ID, ORSAB) and genotypic (polymerase chain reaction) biotyping techniques. All the mecA+ strains harboured the SCCmec gene; SCCmec type I prevailed in $43.75 \%$ and $p v l$ was found in $\mathbf{4 2 . 1 \%}$ of the isolates. Dual carriage of mecA and pvl genes occurred in six $(37.5 \%, n=6 / 16)$ strains. Overall, majority of the mecA+ MRSA strains documented in this study carried SCCmec elements of the HA genotype with a hint of community-acquired (CA)- genotype suggesting a possible coexistence of both HA-MRSA and community-acquired- healthcare-acquired meticillin-resistant Staphylococcus aureus (CA-MRSA) strains. Consequently, the implementation of methodical surveillance is needed for the evaluation of potential shifts in directionality of (HA-MRSA/CA-MRSA) pvl+ MRSA clones in our hospitals for effective and prudent antimicrobial stewardship.

Key words: mecA, SCCmec, pvl, healthcare-acquired meticillin-resistant Staphylococcus aureus (HAMRSA), community-acquired meticillin-resistant Staphylococcus aureus (CA-MRSA), Staphylococcus aureus 


\section{INTRODUCTION}

Acquisition of mecA gene mediates the acquisition of methicillin resistance by encoding the production of altered penicillin binding protein (PBP2a) housed on a genomic island called staphylococcal cassette chromosome mec (SCCmec), a mobilizable genetic element that integrates into the specific position in the chromosome (1). These elements differ in size from $20 \mathrm{~kb}$ to about $60 \mathrm{~kb}$ and are classified into types based on the orientation of mecA regulators (mecR1/mecI) and recombinases (ccrAB and ccrC) that ease SCCmec excision, circularization, and insertion in chromosome (2). SCCmec island houses the ccr complex, the mec complex and the 'Junkyard area'. The first of these cassettes (SCCmec I) was initially identified at the end of the $20^{\text {th }}$ century in Staphylococcus aureus. Subsequently, two others (SCCmec II and III) were found from different MRSA strains (3). Contemporarily, novel types of SCCmec elements, like IV to XI and several new variants of already identified SCCmec types have been documented (4). Anecdotally, the lines of distinction between SCCmec types among community and hospitals is diminishing worldwide. The majority of hospital-acquired MRSA(HA-MRSA) and community-acquired MRSA (CA-MRSA) isolates still carry the SCCmec type's I-III and SCCmec types $\mathrm{IV}-\mathrm{V}$, respectively (4). Nonetheless, the carriage of SCCmec types IV-V is not an all-encompassing characteristic of CA-MRSA because unlike the larger mobile elements of type I to III, genomic islands IV$\mathrm{V}$ are small and easily transferable which may spillover to HA-MRSA (5).

In the $20^{\text {th }}$ century, Noel Panton and Francis Valentine associated a leukocyte lysing, cytolytic gamma toxin latter called Panton-Valentine leukocidin (PVL) with soft tissue infections $(6,7)$. Though initially disregarded and perceived to be restricted to secondary infections (8), the findings of polt S. aureus (PPSA) among patients without predisposing risk factors heralded an apprehensiveness and existential discomfort amongst healthcare workers and researchers that came to the realization of its particulars and its potential effect on health care. Even with its documented epidemiological association to CA-MRSA (69-98\%) infections, it has not been definitively proven to be a major virulence determinant for the strain (9). We caught up on literatures from previous studies that yielded conflicting results and linked the $\gamma$-hemolysin homologue with HAMRSA strains $(10-14)$.

S. aureus-pol is encoded by co-transcribed Protoxin subunits (F and S) of Panton-Valentine (PV) leukocidin (Luks) genes found in the genomes of $S$. aureus associated bacteriophage $(8,15,16)$. The PVL toxin targets the cell membrane of leukocytes and increases its permeability (by forming pores) that leads to cellular degradation and necrosis $(17,18)$. In severe infections, this will result in a decrease in leukocytes count, increases in S. aureus virulence, responsible for intense necrotic skin infections $(19,20)$. The pol gene is carried by methicillin susceptible (MSSA) and resistant (MRSA) S. aureus $(7,21)$. The contribution of pol in musculoskeletal disorders, necrotizing pneumonia, and brain abscess has been documented. PPSA associated highly transmissible therapy-refractory skin infections, and life-threatening hemoptysis has been on the rise globally ( 8 , 22).

The prevalence of HA-MRSA (based on mecA+ strains) in hospitals in Nigeria may differ from $1.5 \%$ to $20 \%$ (23). The purpose of this study was to determine the constellation of SCCmec types among mecA positive (mecA+) MRSA nasal isolates in our study center.

\section{MATERIALS AND METHODS}

\section{Confidentiality and ethical considerations}

Ethical review board of Sokoto State Ministry of Health in Nigeria approved this study $(\mathrm{SMH} /$ 1580/V. IV). Informed consent was obtained from the study participants and information gathered were documented anonymously.

\section{Study center, sample collection and processing}

This study was conducted in three Sokoto state-owned hospitals in 2018 (Maryam Abacha Women and Children Hospital, Specialist Hospital and Orthopedic hospital Wamakko). Nasal swabs were randomly collected from 378 participants (healthcare workers, inpatients, outpatients, security men and cleaners) using commercially available swab sticks and processed as per standard microbiological procedures for the recovery of $S$. aureus (24). Biotyping for S. aureus was based on growth 
Mannitol salt agar, Gram staining characteristics, spot tests (catalase and coagulase) and the Microgen $^{\text {TM }}$ Staph ID kit.

\section{Oxacillin resistance screening agar base (ORSAB) test}

A standardized suspension ( 0.5 McFarland) of S. aureus isolates were prepared and inoculated onto ORSAB medium pre-supplemented with $6 \mu \mathrm{g} / \mathrm{ml}$ oxacillin and $4 \%$ sodium chloride and incubated at $35^{\circ} \mathrm{C}$ overnight. The emergent bluish colonies from the overnight cultures were considered methicillin resistant (25).

\section{Polymerase chain reaction}

The presumptive isolates were additionally queried by two different multiplex PCRs. The first multiplex PCR was done for the detection of methicillin resistance (mecA gene) and leukocidin toxin gene ( $p v l)$ (Table 1). The second multiplex PCR was done for typing SCCmec elements of mecA positive MRSA strains (Table 1). The primers used were calculated using Primer3Plus ${ }^{\circledR}$ based on partial coding sequences of genes of interest obtained from GenBank/NCBI (26). PCR simulation was executed using Snap Gene ${ }^{\mathrm{TM}}$ software (version 1.1.3) to determine the efficiency and the validity of the expected amplicon sizes of the proposed primers before its production (Assumption-free). Total bacterial genomic DNA was extracted from 24 hours culture on nutrient agar using the Qiagen ${ }^{\mathrm{TM}}$ DNA extraction kit (Qiagen, Hilden, Germany) in accordance with the manufacturer's protocols. The first PCR for the detection of mecA and pol gene was done using the protocol given by (27) and the second PCR for the typing and subtyping of the SCCmec elements was carried out as follows. The reaction was performed in the final volume of $25 \mu \mathrm{L}$, involving $4 \mu \mathrm{L}$ of DNA template, $12.5 \mu \mathrm{l}$ of Qiagen master mix, $2.5 \mu \mathrm{L}$ of Qreagent, $0.5 \mu \mathrm{L}$ of each primer pair ( $3 \mu \mathrm{L}$ totally) and $3 \mu \mathrm{l}$ molecular grade water. DNA was amplified with a thermocycler (Applied bio systems 9700), and multiplex PCR conditions were as follows: initial denaturation for 3 minutes at $94^{\circ} \mathrm{C}, 35$ cycles of denaturation at $94^{\circ} \mathrm{C}$ for 40 seconds, annealing at $56^{\circ} \mathrm{C}$ for 45 seconds, and extension at $72^{\circ} \mathrm{C}$ for 1 minute. The final extension was carried out at $72^{\circ} \mathrm{C}$ for 4 minutes. The PCR amplicons were visualized on $1.5 \%$ agarose gel pre-stained with ethidium bromide using a $100 \mathrm{bp}+$ ladder (Bio-labs, New England, UK). They were documented with BIO-RAD gel-doc (Milan, Italy) under a UV transilluminator and analyzed with image lab ${ }^{\mathrm{TM}} 6.01$ software (BIO-RAD, Milan, Italy) and Applied Maths Bionumerics version 7.0 (Sint-Martens-Latem, Belgium).

Table 1. The primer sequence of the studied genes

\begin{tabular}{|c|c|c|c|c|c|}
\hline Primer & & Sequence (5' -- > 3') & Product & $\mathbf{T m}$ & Accession \\
\hline \multirow[t]{2}{*}{ SCCmec I } & $\mathrm{F}$ & TCGGGTGAAAGTGATGACAC & 495 bp & $59.5^{\circ} \mathrm{C}$ & CCJ25736 \\
\hline & $\mathrm{R}$ & GCGGTAATTGATATCCAGCAA & & & \\
\hline \multirow[t]{2}{*}{ SCCmec IIa } & $\mathrm{F}$ & TGGCGATGACGATATTGAAG & 284 bp & $59.65^{\circ} \mathrm{C}$ & AB774377 \\
\hline & $\mathrm{R}$ & ACCGCAGAAGATGACGAACT & & & \\
\hline \multirow[t]{2}{*}{ SCCmec IIb } & $\mathrm{F}$ & AGGTTTGAAGCGGTTTTTCA & $381 \mathrm{bp}$ & $59.72^{\circ} \mathrm{C}$ & AB127982 \\
\hline & $\mathrm{R}$ & CTTCTAACGCTTCGCATTCC & & & \\
\hline \multirow[t]{2}{*}{ SCCmec III } & $\mathrm{F}$ & TCCCATATCGGAAAGAATCG & 313bp & $59.86^{\circ} \mathrm{C}$ & AB047089 \\
\hline & $\mathrm{R}$ & ACTTGCTGCATCCACTGTTG & & & \\
\hline \multirow[t]{2}{*}{ SCCmec IVa } & $\mathrm{F}$ & TTTGAGGTTTTCGGGTGTTC & 450 bp & $59.95^{\circ} \mathrm{C}$ & AB266531 \\
\hline & $\mathrm{R}$ & TGCATGCACAGTGATAACGA & & & \\
\hline \multirow[t]{2}{*}{ SCCmec IVb } & $\mathrm{F}$ & TGCATGCACAGTGATAACGA & $1 \mathrm{~kb}$ & $59.86^{\circ} \mathrm{C}$ & AB063173 \\
\hline & $\mathrm{R}$ & TTTGAGGTTTTCGGGTGTTC & & & \\
\hline \multirow[t]{2}{*}{ mecA } & $\mathrm{F}$ & TGGTAAAGGTTGGCAAAAAGA & 533bp & $59.6^{\circ} \mathrm{C}$ & KY788636 \\
\hline & $\mathrm{R}$ & TTGTCCGTAACCGGAATCA & & & \\
\hline \multirow[t]{2}{*}{ Pvl } & $\mathrm{F}$ & TAAGGGCAAACACTTGTGGA & 433bp & $59.8^{\circ} \mathrm{C}$ & HQ020533 \\
\hline & $\mathrm{R}$ & CCATTTGATCAAGACGAGCA & & & \\
\hline
\end{tabular}




\section{Statistical method}

Descriptive statistics were used to present the study outcomes. Each study variable was compared between SCCmec types. Variables were summarized as proportions (\%). Statistical analysis was done using SAS version 9.4 software (SAS, Cary, NC, USA).

\section{RESULTS}

We studied eighty-one phenotypic S. aureus nasal isolates from state-owned hospitals and ar- rived at thirty-eight phenotypically confirmed MRSA strains out of which 16 were PCR- positive for mecA and 17 for pol gene (Figure 1). Dual carriage of mecA and pol occurred in six $(37.5 \%, \mathrm{n}=6 / 16)$ strains. The isolates were resolved into four clades: A, B, C and D with decreasing PCR profile similarity. Cluster A housed mecAt-pvlt strains. Clade B comprised mecA+ stains, C housed pvlt and D was PCR-negative. Further, we amplified SCCmec from all strains $(100 \%)$ that were PCR-positive for the mecA gene (Figure 2). SCCmec type I prevailed in $43.75 \%$, type IIA in $18.75 \%$, type IIB in $12.50 \%$, type

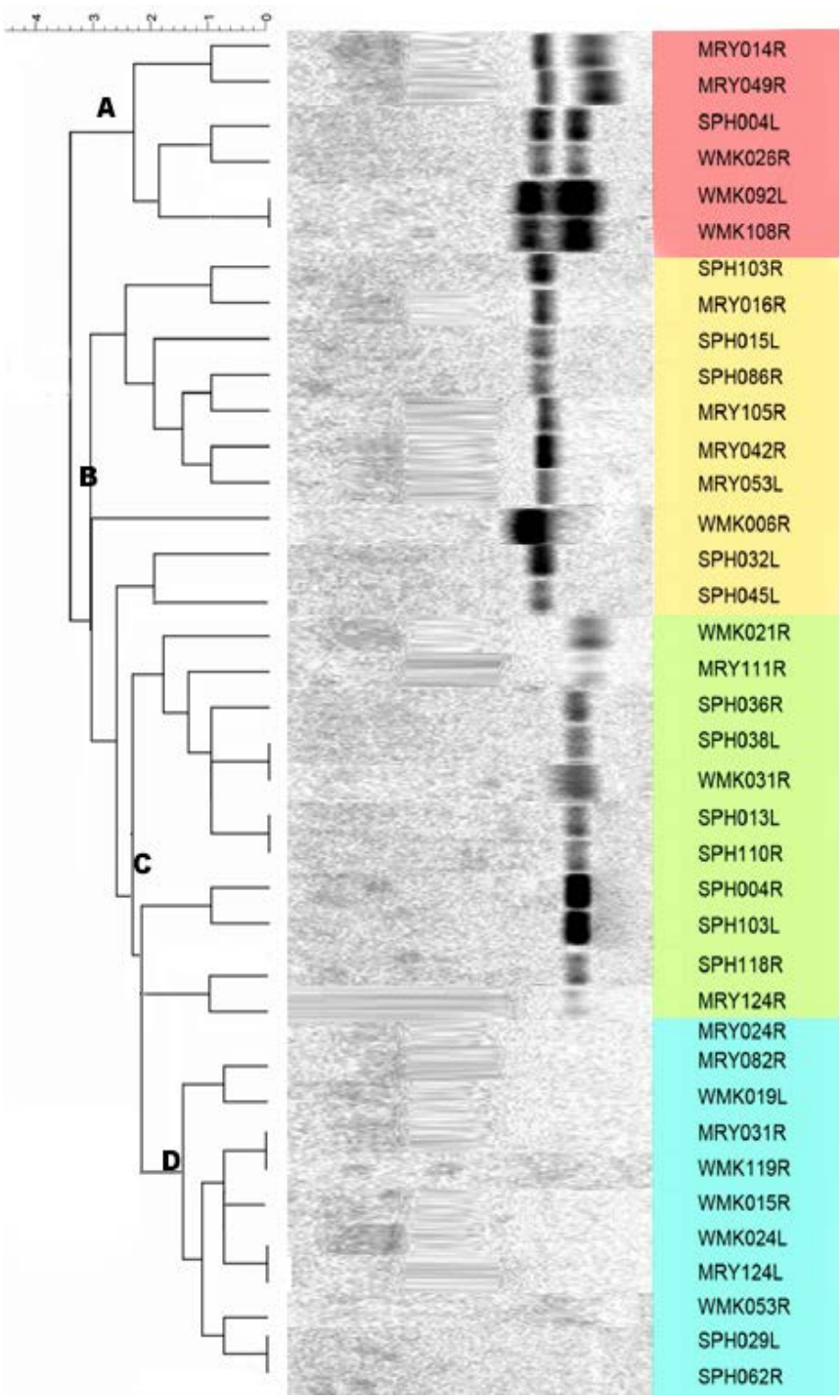

Figure 1. A clustering tree of DNA gel fingerprint resolved from electropherograph showing MRSA strains segregated based on their SCCmec type in groups of various sizes. In the figure, clustering identified four clades based on banding profiles; a scale bar indicates a degree of similarity. Note: Red $=P C R$-positive for dual carriage of mecA and pol; Yellow = PCR-positive for mecA only; Green = PCR positive for pol gene only, and Blue = PCR negative strains. 


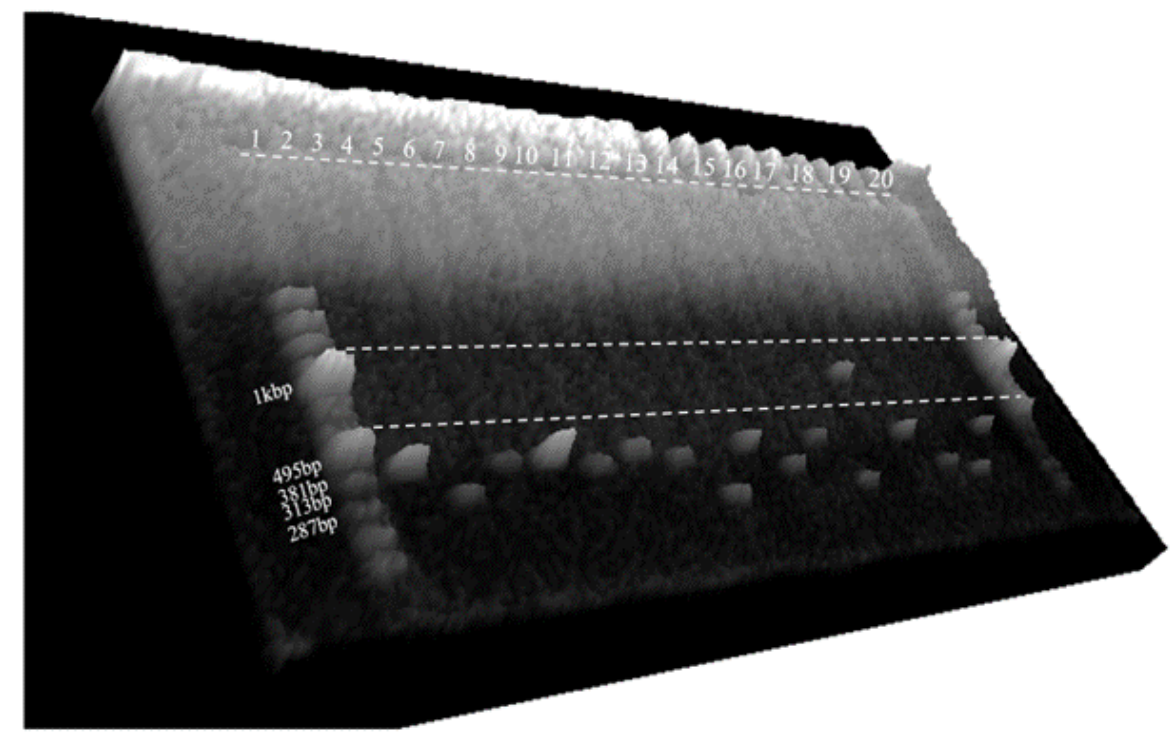

Figure 2. Three-dimensional electrophoretogram of ethidium bromide-stained gel showing amplification of SCCmec I (495 bp), SCCmec IIa (284 bp), SCCmec IIb (381 bp), SCCmec III (313 bp), SCCmec IVa (450bp), and SCCmec IVb (1kb) from $16 \mathrm{mec} A$ positive MRSA strains. In the figure, Lane 1 and $20=100 \mathrm{bp}+\mathrm{DNA}$ ladder, Lane $2=S$. aureus ATCC 25923 (Positive control), Lane 3 - 18= Contain all 16 MRSA strains and Lane $19=$ Negative control

(Nuclease-free water)

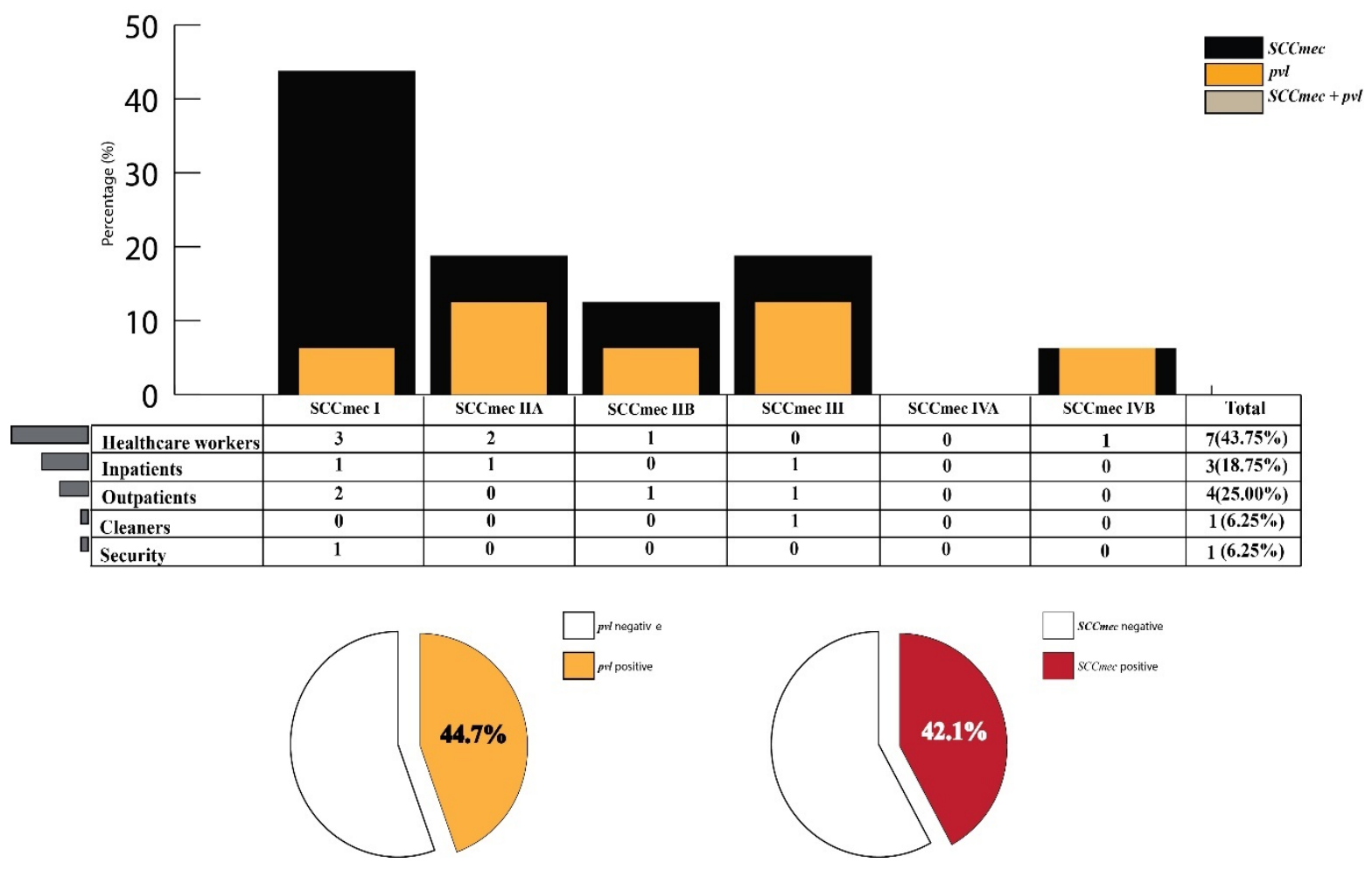

Figure 3. Percentage distribution of SCCmec and pol genes of mecA positive MRSA strains 


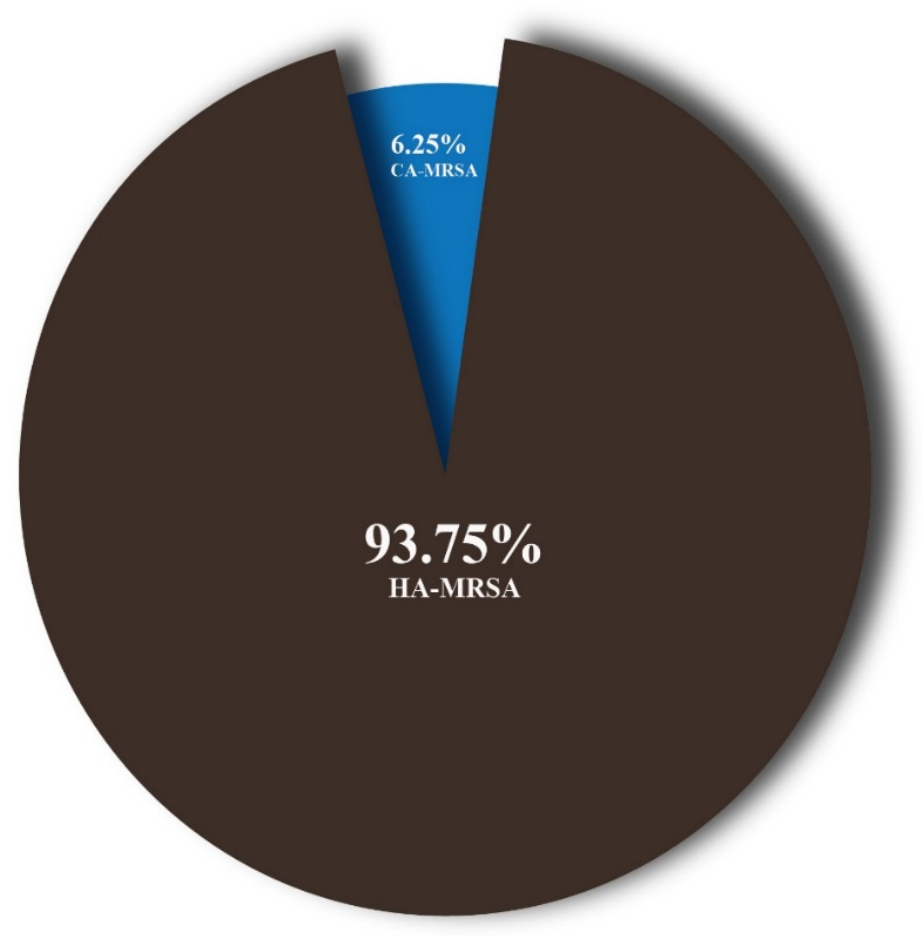

Figure 4: Distribution of HA-MRSA and CA-MRSA strains amongst mecA positive strains

III in $18.75 \%$ and type IVA in $6.25 \%$ of the MRSA isolates. None of the isolates were typable for SCCmec type IVA (Figure 3). The pol gene was documented in $6.25 \%$ of stains typed SCCmec I, IIB and IVB, and $12.5 \%$ of SCCmec IIA and III typed strains. Overall, the prevalence of SCCmec and pol gene was $42.1 \%$ and $44.7 \%$, respectively. We encountered SCCmec gene among healthcare workers (43.75\%), inpatients $(18.75 \%)$, outpatients $(25 \%)$, cleaners $(6.25 \%)$ and security men (6.25\%). Most of the mecA positive isolates that harbored both SCCmec gene and pol genes originated from healthcare workers and inpatients. Almost all the mecA+ strains were HA-MRSA (Figure 4).

\section{DISCUSSION}

In this work, we provided genotypic data on 38 phenotypic MRSA strains discovered during a six-month period in Sokoto state-owned hospital in order to elucidate the genetic pool and potential emergence of unexpected MRSA strains. The mecA carrying MRSA strains prevailed in $42.1 \%$ of phenotypic methicillin resistant strains amongst the hospital with a $93.75 \%$ presence of HA-MRSA. This prevalence of HA-MRSA strains carrying a HA genotype in this study was higher than previous rates reported by Okwu et al. (28), Ghebremedhin et al. (29), Pathare et al. (30), Mohajeri et al. (31), and Parvez et al. (32) that documented the occurrence rates of $59 \%, 52.85 \%, 15.1 \%, 36.8 \%$ and $40 \%$, respectively.

A pertinent proportion of mecA positive MRSA strains with HA genotype was associated with healthcare workers carrying SCCmec I, II, and III confirming that most of carried strains emerged from health care settings. Possible reasons for the assortment of SCCmec type might be due to differences in geographical regions, the study population, and detection methods. SCCmec types IVB was rare and carried by $6.25 \%$ of the strains. This cassette type is traditionally attributed to CA-MRSA $(10,33)$. Our result is dissident with those documented by mathematical models that posited the replacement of traditional HA-MRSA strains by CA-MRSA strains, due to their higher growth rate and greater fitness (3), but conforms with the models that hospitalcommunity interactions provoke coexistence among methicillin resistant strains of $S$. aureus. $(34-36)$. HA and CA strains of MRSA can coexist if the wider resistance range of the HA strains is balanced by transitional fitness-disadvantages in the presence of resistant strains. The HA strains are better selected in the hospital, where antibiotics are regularly used, but community-associated strains thrive (higher fit- 
ness) in the community where the use of antibiotics is relatively low (opposite directions of selection) (34). Despite conflicting directions of selection, these strains exist in both settings because of the high rates of hospitalization and discharge, which rotates individuals between the hospital and the community. Besides, our results also specify that opposite directions of selection are not adequate for maintaining coexistence (34).

The carriage of $p v l$ gene $(p v l+)$ in $44.7 \%$ of MRSA isolates in this report is consistent with $58.8 \%$ reported by Govindan et al. (37) and in dissidence with reports from Nigeria (16\%) (38), Egypt (2.2\%) (39), Uganda (73\%) (40). In our study, among the tested mecA+ MRSA isolates, pvl+ was chiefly associated with HA genotype (37.5\%). Previous studies have recognized that the pvl genes are carried mostly by CA-MRSA $(41,42)$. Paradoxically, pol-carrying HA-MRSA strains have also been previously described (23).

Lastly, this study had a few limitations. First, the study was conducted in a few healthcare centers and may have biased the representativeness of the isolates herein studied. Second, clinical features were not considered in characterizing both CA-MRSA and HA-MRSA. We used only genotypic characteristics to classify MRSA.

\section{CONCLUSION}

Overall, majority of MRSA recovered in our study centres carried diverse SCCmec elements of the HA genotype with a hint of CA- genotype. We documented the dominance HA-MRSA-pvl+. Our data also revealed the presence of CA-MRSA strains suggesting a possible coexistence of both HA-MRSA and CA-MRSA strains. Consequently, implementing methodical surveillance is needed for the evaluation of shift in directionality of (HA-MRSA/CATOXNMRSA) pvl+ clones in our hospitals for effective and prudent antimicrobial stewardship.

\section{Conflict of interest}

All authors declare to have no conflict of interest. 


\section{References}

1. Galia L, Ligozzi M, Bertoncelli A, et al. Real-time PCR assay for detection of Staphylococcus aureus, Panton-Valentine Leucocidin and Methicillin Resistance directly from clinical samples. AIMS Microbiol 2019;5:138-46. https://doi.org/10.3934/microbiol.2019.2.138

2. Vestergaard $M$, Frees $D$, Ingmer $H$. Antibiotic resistance and the MRSA problem. Gram-Posit Pathog2019;747-65.

https://doi.org/10.1128/9781683670131.ch47

3. Lakhundi S, Zhang K. Methicillin-Resistant Staphylococcus aureus: Molecular Characterization, Evolution, and Epidemiology [Internet]. Clin Microbiol Rev 2018;31[cited 2020 Feb 16] Available from:

https://www.ncbi.nlm.nih.gov/pmc/articles/PMC6 $\underline{148192 /}$

4. Peng H, Liu D, Ma Y, et al. Comparison of community- and healthcare-associated methicillinresistant Staphylococcus aureus isolates at a Chinese tertiary hospital, 2012-2017 [Internet]. Sci Rep 2018;8[cited 2020 Feb 16] Available from: https://www.ncbi.nlm.nih.gov/pmc/articles/PMC6 $\underline{297250 /}$

5. Yousuf B, Nargis B. SCCmec Type IV and V Methicillin Resistant Staphylococcus aureus Intrusion in Healthcare Settings. Am J Clin Microbiol Antimicrob 2019; 2(1): 1032.

6. Shallcross LJ, Williams K, Hopkins S, et al. Panton-Valentine leukocidin associated staphylococcal disease: a cross-sectional study at a London hospital, England. Clin Microbiol Infect 2010;16:1644-8.

https://doi.org/10.1111/j.1469-0691.2010.03153.x

7. Bhatta DR, Cavaco LM, Nath G, et al. Association of Panton Valentine Leukocidin (PVL) genes with methicillin resistant Staphylococcus aureus (MRSA) in Western Nepal: a matter of concern for community infections (a hospital based prospective study). BMC Infect Dis 2016;16:199.

https://doi.org/10.1186/s12879-016-1531-1

8. Okolie CE, Cockayne A, Penfold C, et al. Engineering of the LukS-PV and LukF-PV subunits of Staphylococcus aureus Panton-Valentine leukocidin for Diagnostic and Therapeutic Applications. BMC Biotechnol 2013;13:103. https://doi.org/10.1186/1472-6750-13-103

9. Shallcross LJ, Fragaszy E, Johnson AM, et al. The role of the Panton-Valentine leucocidin toxin in staphylococcal disease: a systematic review and meta-analysis. Lancet Infect Dis 2013;13:43-54. https://doi.org/10.1016/S1473-3099(12)70238-4

10. Hu $\mathrm{Q}$, Cheng $\mathrm{H}$, Yuan $\mathrm{W}$, et al. Panton-Valentine Leukocidin (PVL)-Positive Health CareAssociated Methicillin-Resistant Staphylococcus aureus Isolates Are Associated with Skin and Soft Tissue Infections and Colonized Mainly by Infective PVL-Encoding Bacteriophages. J Clin Microbiol 2015;53:67-72. https://doi.org/10.1128/ICM.01722-14

11. Khairalla AS, Wasfi R, Ashour HM. Carriage frequency, phenotypic, and genotypic characteristics of methicillin-resistant Staphylococcus aureus isolated from dental health-care personnel, patients, and environment. Sci Rep 2017;7:1-16.

https://doi.org/10.1038/s41598-017-07713-8

12. Kleinwaks LP, Leung B, Sen B, et al. PVL toxinproducing methicillin-resistant Staphylococcus aureus (MRSA) are predominant in a tertiary-care metropolitan teaching hospital. Can J Infect Control 2017;32:143-5.

13. Tajik S, Najar-Peerayeh S, Bakhshi B. Hospital clones of Panton-Valentine leukocidin positive and methicillin-resistant Staphylococcus aureus are circulating in the community of Tehran [Internet]. 
J Glob Antimicrob Resist 2019;[cited 2020 Feb 16] Available from: https://doi.org/10.1016/j.jgar.2019.12.010

14. Qin Y, Wen F, Zheng Y, et al. Antimicrobial resistance and molecular characteristics of methicillin-resistant Staphylococcus aureus isolates from child patients of high-risk wards in Shenzhen, China. Jpn J Infect Dis 2017;JJID-2016. https://doi.org/10.7883/yoken.JIID.2016.328

15. Melles DC, Leeuwen WB van, Boelens HAM, et al. Panton-Valentine Leukocidin Genes in Staphylococcus aureus. Emerg Infect Dis 2006;12:1174-5. https://doi.org/10.3201/eid1207.050865

16. Funaki T, Yasuhara T, Kugawa S, et al. SCCmec typing of PVL-positive community-acquired Staphylococcus aureus (CA-MRSA) at a Japanese hospital. Heliyon 2019;5:e01415. https://doi.org/10.1016/j.heliyon.2019.e01415

17. Los FCO, Randis TM, Aroian RV, et al. Role of Pore-Forming Toxins in Bacterial Infectious Diseases. Microbiol Mol Biol Rev 2013;77:173-207. https://doi.org/10.1128/MMBR.00052-12

18. Sultan AM, Nabiel Y. Association of tsst- 1 and pvl with mecA Genes among Clinical Staphylococcus aureus Isolates from a Tertiary Care Hospital. J Pure Appl Microbiol 2019;13:855-64. https://doi.org/10.22207/JPAM.13.2.21

19. Vidal C, Moulin F, Nassif X, et al. Fulminant arterial vasculitis as an unusual complication of disseminated staphylococcal disease due to the emerging CC1 methicillin-susceptible Staphylococcus aureus clone: a case report. BMC Infect Dis 2019;19:302. https://doi.org/10.1186/s12879-019-3933-3

20. Pei S, Morone F, Liljeros F, et al. Inference and control of the nosocomial transmission of methicillin-resistant Staphylococcus aureus. eLife 2018;7:e40977.

https://doi.org/10.7554/eLife.40977

21. Shrestha B, Singh W, Raj VS, et al. High Prevalence of Panton-Valentine Leukocidin (PVL) Genes in Nosocomial-Acquired Staphylococcus aureus Isolated from Tertiary Care Hospitals in Nepal [Internet]. BioMed Res Int 2014;2014[cited $2020 \mathrm{Feb} 16]$ Available from:

https://www.ncbi.nlm.nih.gov/pmc/articles/PMC4 $\underline{087282}$

22. Jung $N$, Lehmann C, Hellmann $M$, et al. Necrotizing Pneumonia Caused by PantonValentine Leucocidin-Producing Staphylococcus aureus Originating from a Bartholin's Abscess [Internet]. Infect Dis Obstet Gynecol 2008;[cited 2020 Feb 16] Available from:

https://www.hindawi.com/journals/idog/2008/491401

23. Abdulgader SM, Shittu AO, Nicol MP, et al. Molecular epidemiology of Methicillin-resistant Staphylococcus aureus in Africa: a systematic review [Internet]. Front Microbiol 2015;6[cited 2019 Dec 20] Available from:

https://www.frontiersin.org/articles/10.3389/fmicb $.2015 .00348 /$ full

24. Weinstein MP, Clinical and Laboratory Standards Institute. Performance standards for antimicrobial susceptibility testing. 2019.

25. Correia S, Silva V, García-Díez J, et al. One Health Approach Reveals the Absence of MethicillinResistant Staphylococcus aureus in Autochthonous Cattle and Their Environments [Internet]. Front Microbiol 2019;10[cited 2019 Dec 25] Available from:

https://www.frontiersin.org/articles/10.3389/fmicb $.2019 .02735 /$ full

26. Untergasser A, Nijveen $H$, Rao $X$, et al. Primer3Plus, an enhanced web interface to Primer3. Nucleic Acids Res 2007;35:W71-W74. https://doi.org/10.1093/nar/gkm306

27. Hefzy EM, Hassan GM. Rapid Molecular Identification of Hospital-acquired Methicillin Resistant Staphylococcus aureus (HA-MRSA) Lineages. Egypt J Med Microbiol 2016;38:1-7.

28. Okwu M, Sinat B, Aborisade W. Prevalence of Nasal Carriage of Community-associated Methicillin- resistant Staphylococcus aureus (CAMRSA) among Healthy Primary School Children in Okada, Nigeria - Semantic Scholar. J Nat Sci Res 2012;4(2): 2224-3186. 
29. Ghebremedhin B, Olugbosi MO, Raji AM, et al Emergence of a Community-Associated Methicillin-Resistant Staphylococcus aureus Strain with a Unique Resistance Profile in Southwest Nigeria. J Clin Microbiol 2009;47:2975-80. https://doi.org/10.1128/JCM.00648-09

30. Pathare NA, Asogan H, Tejani S, et al. Prevalence of methicillin resistant Staphylococcus aureus [MRSA] colonization or carriage among healthcare workers. J Infect Public Health 2016;9:571-6. https://doi.org/10.1016/i.jiph.2015.12.004

31. Mohajeri P, Izadi B, Rezaei M, et al. Frequency Distribution of Hospital-Acquired MRSA Nasal Carriage Among Hospitalized Patients in West of Iran [Internet]. Jundishapur J Microbiol 2013; 6 [cited 2020 Feb 9] Available from: http://jimicrobiol.com/en/articles/18656.html

32. Parvez N, Jinadatha $C$, Fader $R$, et al. Universal MRSA nasal surveillance: characterization of outcomes at a tertiary care center and implications for infection control. South Med J 2010;103:1084-91. https://doi.org/10.1097/SMJ.0b013e3181f69235

33. Nagasundaram N, Sistla S. Existence of multiple SCCmec elements in clinical isolates of methicillinresistant Staphylococcus aureus. J Med Microbiol 2019;68:720-7.

https://doi.org/10.1099/jmm.0.000977

34. Kouyos R, Klein E, Grenfell B. Hospital-Community Interactions Foster Coexistence between MethicillinResistant Strains of Staphylococcus aureus. PLoS Pathog 2013;9:e1003134.

https://doi.org/10.1371/journal.ppat.1003134

35. Kouyos RD, Abel zur Wiesch P, Bonhoeffer S. On Being the Right Size: The Impact of Population Size and Stochastic Effects on the Evolution of Drug Resistance in Hospitals and the Community [Internet]. PLoS Pathog 2011;7[cited 2020 Feb 16] Available from: https://www.ncbi.nlm.nih.gov/pmc/articles/PMC3 $\underline{077359}$
36. Mairpady Shambat S. Host-pathogen interactions in invasive Staphylococcus aureus infections [Internet]. Inst för medicin, Huddinge / Dept of Medicine, Huddinge; 2016. [cited 2020 Feb 16] Available from: http://openarchive.ki.se/xmlui/handle/10616/45144

37. Govindan S, Maroli AS, Ciraj AM, et al. Molecular epidemiology of methicillin resistant Staphylococcus aureus colonizing the anterior Nares of school children of Udupi Taluk. Indian J Med Microbiol 2015;33:129. https://doi.org/10.4103/0255-0857.150919

38. Anyanwu NCJ, Abdullahi IO, Ameh JB, et al. Molecular detection of PVL, msrA genes and antibiotic susceptibility pattern of Staphylococcus aureus from skin and soft tissue infections in Zaria, Nigeria. Sci J Microbiol 2013;2(22): 43-52.

39. Hefzy EM, Hassan GM, Abd El Reheem F. Detection of Panton-Valentine LeukocidinPositive Methicillin-Resistant Staphylococcus aureus Nasal Carriage among Egyptian Health Care Workers. Surg Infect 2016;17:369-75. https://doi.org/10.1089/sur.2015.192

40. Kateete DP, Namazzi S, Okee M, et al. High prevalence of methicillin resistant Staphylococcus aureus in the surgical units of Mulago hospital in Kampala, Uganda. BMC Res Notes 2011;4:326. https://doi.org/10.1186/1756-0500-4-326

41. Vandenesch F, Naimi T, Enright MC, et al. Community-Acquired Methicillin-Resistant Staphylococcus aureus Carrying Panton-Valentine Leukocidin Genes: Worldwide Emergence. Emerg Infect Dis 2003;9:978-84. https://doi.org/10.3201/eid0908.030089

42. Naimi TS, LeDell KH, Como-Sabetti K, et al. Comparison of Community- and Health CareAssociated Methicillin-Resistant Staphylococcus aureus Infection. JAMA 2003;290:2976-84. https://doi.org/10.1001/jama.290.22.2976 


\title{
Konstelacija genomskih ostrva (SCCmec) rezistentnih na meticilin kod nazalnih izolata Staphylococcusa aureusa rezistentnog na meticilin
}

\author{
Shuaibu Suleiman Adeiza, Josiah Ademola Onaolapo, Busayo Olalekan Olayinka \\ Departman za farmaceutsku mikrobiologiju, Facultet farmaceutskih nauka, Univerzitet Ahmadu Bello, \\ Zaria, Kaduna, Nigerija
}

\section{S AŽETAK}

Zabrinutost zbog vakuuma u znanju o egzistencijalnoj opasnosti nazalnog nosilaštva $p v l+$ HA-MRSA sojeva kod hospitalizovanih navela nas je da bolje istražimo konstelaciju SCCmec tipova i pvl-gena kod mecA pozitivnih sojeva u slučaju nazalnog kliconoštva meticilin-rezistentnog Staphylococcusa aureusa. Iz ovog razloga urađene su fenotipske (catalaza, coagulaza, Microgen staph ID, ORSAB) kao i genotipske (lančana reakcija polimeraze) tehnike biotipizacije. Svi mecA+ sojevi sadržali su SCCmec gen; SCCmec tip I preovladavao je kod $43,75 \%$ izolata, a $p v l$ kod $42,1 \%$ izolata. Dualno nosilaštvo mecA i $p v l$ gena zabeleženo je kod $6(37.5 \%, n=6 / 16)$ sojeva. Većina mecA+ MRSA sojeva registrovanih u ovoj studiji nosili su SCCmec elemente HA genotipa sa naznakom CA- genotipa, što je ukazivalo na moguću koegzistenciju HA-MRSA i CA-MRSA sojeva. Kao rezultat ovoga, uvođenje metodičnog nadzora potrebno je zbog procene mogućih promena usmerenosti (HA-MRSA/CA-MRSA) pvl+ MRSA klonova u našim bolnicama kao i efikasnog i pažljivog praćenja antimikrobnih lekova.

Ključne reči: mecA, SCCmec, pvl, HA-MRSA, CA-MRSA, Staphylococcus aureus 